\title{
DisTYLOUS TRAITS IN CORDIA DODECANDRA AND CORDIA Sebestena (Boraginaceae) From the YuCatan Peninsula
}

\author{
César Canché-Collí and Azucena Canto ${ }^{1}$ \\ Centro de Investigación Científica de Yucatán (CICY) Mérida, Yucatán, Mexico \\ ${ }^{1}$ corresponding author: azucanto@cicy.mx
}

\begin{abstract}
Distyly is a genetically-controlled polymorphism with two floral morphs exhibiting spatial, reciprocal separation between stigmas and anthers; one morph presents styles above anthers, and the other styles below anthers. Distyly is usually linked to a self-incompatibility system that prevents self-pollination and crosses between plants of the same morph, thereby ensuring symmetrical mating and equal morph ratios within populations. This study is the first description of distylous traits in the tropical tree species Cordia dodecandra and C. sebestena from the Yucatan Peninsula. Principal components analysis of flower morphological traits identified segregation into two groups with characteristically distylous morphology. Estimation of reciprocal herkogamy using indices showed almost perfect reciprocity in the distance between long and short sexual organs in the two flower morphs of both species. Reciprocity between organs was lower in $C$. dodecandra, suggesting less accuracy in pollen transference between morphs. Self-incompatibility was observed for $C$. dodecandra, but could not be confirmed for $C$. sebestena. However, a 1:1 floral morph ratio within the sampled $C$. sebestena populations suggests the existence of a distylous, self-incompatibility system in this species. Morph distribution in $C$. dodecandra did not follow a typically distylous distribution, suggesting a disruption in population processes such as seed dispersion and seedling establishment in this species. The reported data confirm the existence of the distyly syndrome in the two Cordia species.
\end{abstract}

Key words: distyly, morph ratio, reciprocal herkogamy, self-incompatibility.

Resumen: La distilia es la separación recíproca entre estigma y anteras, entre plantas de una población, pudiéndose distinguir individuos con flores de estilo largo y anteras cortas e individuos con flores de estilo corto y anteras largas. Involucrados en este polimorfismo se encuentran rasgos morfológicos de las flores y una auto-incompatibilidad controlada por un sistema de dos alelos que resulta en una proporción de tipos florales uno a uno dentro de una población. En este trabajo se explora las características de distilia en dos especies cercanas de árboles tropicales que se distribuyen en la duna costera y en los remanentes de huertos mayas en Yucatán. El análisis de componentes principales mostró la segregación de dos grupos de individuos con diferente morfología floral en ambas especies. Los índices de reciprocidad señalaron que la hercogamia entre los órganos largos y cortos se ajusta de forma casi perfecta a lo esperado en un sistema distílico con autoincompatibilidad sexual en Cordia sebestena y C. dodecandra. Sin embargo, en esta última especie se observó una mayor variación en la precisión en la posición de los órganos recíprocos, pudiendo tener consecuencias en la exactitud con la que el polen es depositado sobre el estigma. Las pruebas de incompatibilidad realizadas únicamente en C. dodecandra mostraron que los individuos cuyas flores recibieron polen propio o de otro individuo de su mismo morfo floral no produjeron frutos y por el contrario, produjeron frutos si recibieron polen de individuos del otro morfo. La proporción uno a uno entre morfos florales en poblaciones de especies con distilia fue observada solo en una de las especies, lo que destaca la posible disrupción de procesos como la dispersión de semillas y establecimiento de nuevos individuos en $C$. dodecandra.

Palabras clave: autoincompatibilidad, distilia, morfos florales, hercogamia recíproca.

D istyly is a floral polymorphism involving a suite of phenotypic traits. The as-yet-untested assumption is that the distylous traits are inherited as a group of closely linked genes that control floral morphology and enhance outcrossing mechanisms (Ganders, 1979). Species exhibiting this syndrome have two floral morphs: one with long styles and short stamens and another with short styles and long stamens. These are frequently distributed in equal morph ratios within populations (Barrett and Shore, 2008). A sporophytic self-incompatibility system is commonly associated with morphs to prevent selfing and pollinations between plants of the same morph. Distylous flowers may 
also differ in ancillary traits, such as pollen grain size and number, stigmatic papillae morphology, stigma shape and corolla size (Dulberger, 1992; Richards, 1997; McCubbin, 2008; Ferrero et al., 2011; Cohen et al., 2012). Of the floral traits involved in distyly, reciprocal herkogamy is the main morphological component shaping floral morphs (Ganders, 1979). In this morphological arrangement, the reproductive organs in long-styled and short-styled flowers are positioned reciprocally; that is, anthers are below stigmas in longstyled flowers and above stigmas in short-styled (Webb and Lloyd, 1986). In conjunction with ancillary traits and the heteromorphic incompatibility system, reciprocal herkogamy plays a key role in controlling pollen movement between distylous flowers. Therefore, it must be adequately described to understand pollen flow trends, reproductive isolation mechanisms and floral morph ratios in related species and the evolutionary pathways of distyly (Richards and Koptur, 1993; Arroyo and Barrett, 2000; Sánchez et al., 2008; Keller et al., 2012).

Cordia dodecandra and C. sebestena are closely related species that belong to the infrageneric section Cordia
(Miller, 1985; Miller and Nowicke, 1989), and the monophyletic clade Sebestena (Gottschling et al., 2005; MuñozMendoza, 2007). Both species are exclusive to the Atlantic side of the Americas and are similar in morphology, shape and size of flowers and fruits, and even in their pollinators (mainly hummingbirds and large bees; Percival, 1974; Opler et al., 1975; Miller, 1985). They differ in that $C$. sebestena is located in the Caribbean region, occurring mostly on coastal sand dune vegetation, while $C$. dodecandra ranges from dry to semi-evergreen forests throughout southeastern Mexico and into Belize (Miller, 1985). Distyly syndrome was first identified in these species via botanical illustrations and herbarium specimens (Tomlinson, 1974; Miller, 1985; Muñoz-Mendoza, 2007; but see Percival, 1974), but this is the first descriptive study of these species to include more than two floral traits as well as pollination tests to characterize their distylous components. Measurements were taken of floral traits related to distyly, estimates made of degree of reciprocity between styles and stamens, surveys done of morph ratios and pollination experiments run to test (1) if two different floral morphs can be clearly identified for

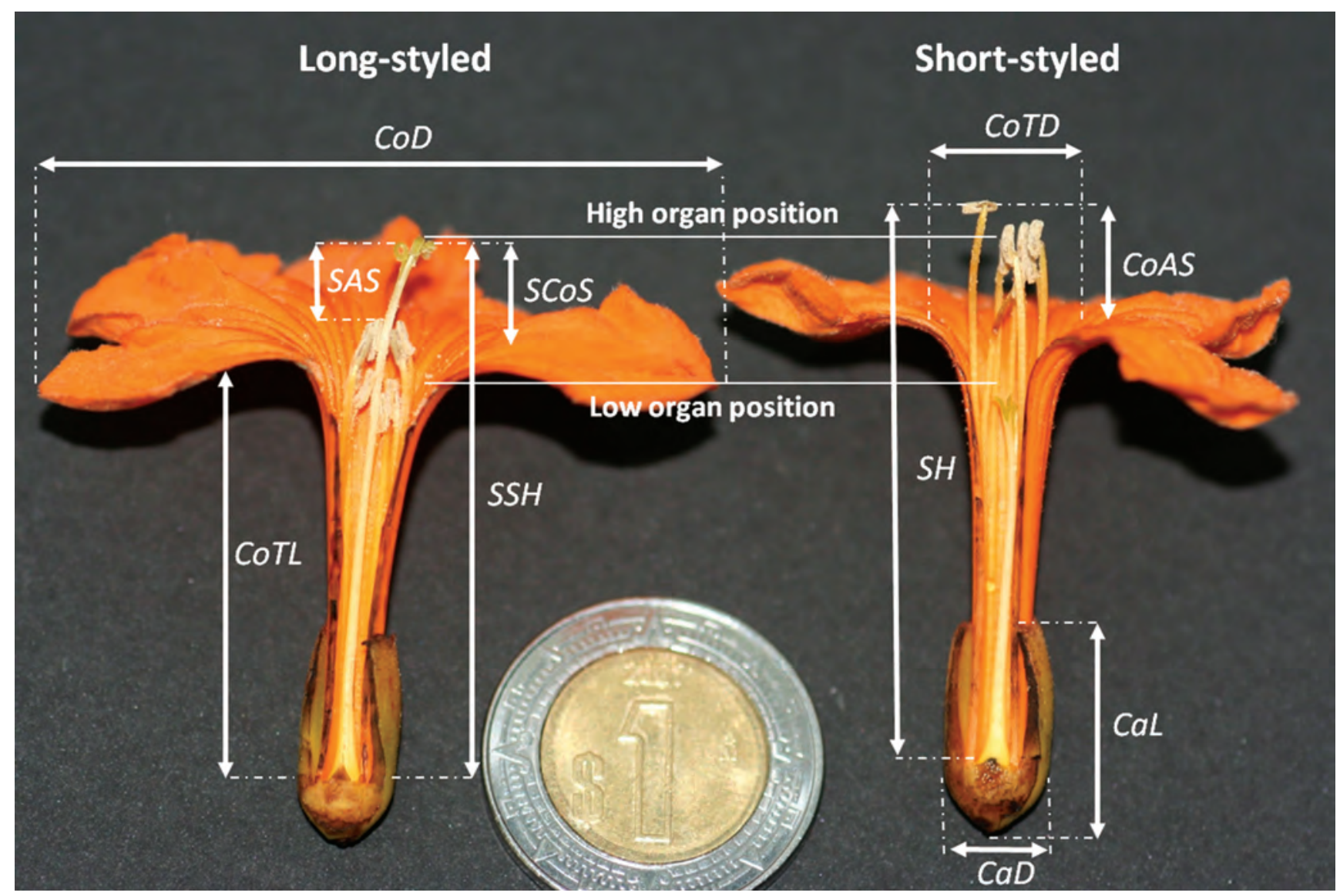

Figure 1. Floral traits measured in long-styled and short-styled Cordia dodecandra flowers (same traits measured in C. sebestena): CaD. calyx diameter; CaL. calyx length; CoD. corolla diameter; CoTL. corolla tube length; CoTD. corolla tube diameter; SCoS. stigma-corolla separation; SAS. stigma-anther separation; SH. stamen height; SSH. style plus stigma height; and CoAS. corolla-anther separation. The number of stamens and corolla lobules were also counted for each flower. 
each species; (2) if reciprocal herkogamy indicating distyly is fully met between these possible morphs; and (3) if a selfincompatibility system can be associated to floral types.

\section{Materials and methods}

Study species. Cordia dodecandra D.C. (Boraginaceae), ciricote or k'oopte in the Maya language, is a deciduous tree, $10 \mathrm{~m}$ in height. Its flowers are large, bright orange in color, gamopetalous and funnel-form with 11-18 lobes and a nearly truncate calyx. Inflorescences are cymose-panicles with hermaphroditic flowers with 13-18 epipetalous stamens that are adnate to the corolla in their lower portion (Miller, 1985). Stamens vary in height from 24 to $31 \mathrm{~mm}$ (CanchéCollí, 2010) and are arranged such that long stamens are intercalated between short ones producing the appearance of two levels of stamens. The style is branching and stigma lobes are clavate. Flowering occurs during the regional dry season, from February to May. The fruits are used by local people to make sweets and the wood is intensively used for the manufacture of high quality furniture, leading to severe reductions in wild populations (Durán-García and Trejo-Torres, 2010; Méndez-González et al., 2010). No longer common in the wild, it is still frequent in cities and in remnant home gardens in rural Mayan towns, where it is found alongside other wild species allowed to grow in these essentially uncultivated spaces (Rico-Gray et al., 1991).

Cordia sebestena L. (Boraginaceae) or anacahuita grows as a shrub or small tree with a maximum height of about $8 \mathrm{~m}$. Its corolla is large, red-orange in color, gamopetalous and funnel-form with 5-7 lobes, and the calyx is usually bi-lobed. Inflorescences occur as panicles with hermaphroditic flowers bearing 5-7 epipetalous stamens of similar height, styles are persistent, stigmas are branched and lobes are clavate. Flowering occurs throughout the year and natural stands are common along the Yucatan Peninsula coast, growing in small, spatially interconnected groups (Chan-Vermont et al., 2002).

Study area and sampling sites. Cordia dodecandra individuals were sampled at two sites: (1) the Xíitbal neek' Regional Botanical Garden of the Centro de Investigación Científica de Yucatán (CICY) and adjacent abandoned home gardens; and (2) the Agricultural and Biological Sciences Campus of the Universidad Autónoma de Yucatán (UADY; Table 2). During flowering season (February to May, 2008), ten flowering individuals were selected at the CICY and eight at the UADY. Individuals of this species are actually scarce at these two sites, meaning these samples represent the remaining populations. The sampled individuals had formed part of Mayan home gardens that were later incorporated by these two institutions. They were not deliberately planted but rather constitute naturally-dispersed individuals allowed to grow by the former garden owners. Vegetation at both sites includes herbs, shrubs, and trees from surrounding remnants of dry and sub-humid forests, growing in a nutrient-rich soil environment (Rico-Gray et al., 1991; Benjamin et al., 2001), with 1,005.3 $\mathrm{mm}$ annual rainfall and $26^{\circ} \mathrm{C}$ mean annual temperature. Hummingbirds, occasional native bees and Apis mellifera are the primary pollinators of $C$. dodecandra. At the CICY, the hummingbird species observed pollinating this tree were Amazilia rutila, Archilochus colubris, and Chlorostilbon canivetii (W. Santamaría, 2013, pers. obs.). At the UADY, the observed hummingbird species included A. candida, A. rutila, A. yucatanensis, Anthracothorax prevostii, A. colubris, and $C$. canivetii (MacKinnon, 2005).

Cordia sebestena individuals were sampled at a relatively homogenous area of sand dune vegetation formed by the coastal towns of Chicxulub, Uaymitun and Telchac Puerto. During May and June 2008, individuals were randomly selected from groups of flowering individuals growing in natural stands (sampled points) nearby the towns (Table 2). In this area, small groups of $C$. sebestena form an interconnected strip-like population. The environment is semi-xeric with $370 \mathrm{~mm}$ average annual rainfall and $26^{\circ} \mathrm{C}$ mean annual temperature (Canché-Collí, 2010). Vegetation is low, open scrub dominated by xerophytes, halophyte herbs, thorny bushes, palms and 1-3 m tall small trees growing on sandy, nutrient-poor soils. As with $C$. dodecandra, the principal pollinators of $C$. sebestena are hummingbirds, with occasional visits from native bees and Apis mellifera. Observed hummingbird visitors to $C$. sebestena included Amazilia rutila, Archilochus colubris, Chlorostilbon canivetii, and Doricha eliza (MacKinnon, 2005; W. Santamaría, pers. obs., 2013).

Sampling design and data analysis. For all sampled individuals at each site, five inflorescences from different branches bearing fully open flowers were collected per tree, carefully placed in glass jars in a portable cooler until taken indoors, and then kept at room temperature until analysis. Ten flowers per plant were randomly selected and dissected to measure twelve morphological traits (Figure 1, Table 1) with a digital vernier (0.01 mm accuracy). Principal component analysis (PCA) is effective for revealing patterns in flower morphology without assuming an underlying causal structure of distylous morphology (Hodgins and Barrett, 2008). It was applied here to determine if the combined contribution of measured traits produced a clear separation of floral morphs, and if so, to identify the main traits causing that separation. All variables were left untransformed, except for number of corolla lobules and stamens; these were square-root transformed to meet the assumptions of linearity required for PCA analysis. The analysis was run using the PRINCOMP procedure in the SAS ver. 9.1 software package (SAS Institute, Cary, NC, USA), and setting single flowers as the subjects. This allows identification of the traits causing variation in morphs and their specific contribution to 
Table 1. Average $( \pm \mathrm{SD})(\mathrm{mm})$ for traits measured in Cordia dodecandra and C. sebestena flowers. Number of trees sampled per floral morph (long-styled and short-styled) is indicated in parentheses; ten flowers were measured per individual.

\begin{tabular}{|c|c|c|c|c|}
\hline \multirow[b]{2}{*}{ Floral traits } & \multicolumn{2}{|c|}{ C. dodecandra } & \multicolumn{2}{|c|}{ C. sebestena } \\
\hline & $\begin{array}{c}\text { Long-styled } \\
\text { (8) }\end{array}$ & $\begin{array}{c}\text { Short-styled } \\
\text { (10) }\end{array}$ & $\begin{array}{l}\text { Long-styled } \\
\text { (9) }\end{array}$ & $\begin{array}{c}\text { Short-styled } \\
\text { (11) }\end{array}$ \\
\hline Calyx diameter & $6.7 \pm 0.8$ & $7.0 \pm 1.0$ & $4.7 \pm 0.3$ & $4.9 \pm 0.3$ \\
\hline Calyx length & $14.3 \pm 1.2$ & $14.1 \pm 1.8$ & $16.3 \pm 1.7$ & $17.0 \pm 1.3$ \\
\hline Corolla diameter & $40.2 \pm 5.0$ & $43.1 \pm 7.5$ & $38.8 \pm 3.9$ & $40.0 \pm 3.9$ \\
\hline Corolla tube length & $30.3 \pm 2.7$ & $32.7 \pm 4.4$ & $24.9 \pm 2.7$ & $27.3 \pm 2.2$ \\
\hline Corolla tube diameter & $7.3 \pm 1.0$ & $8.1 \pm 1.1$ & $5.6 \pm 0.7$ & $6.0 \pm 0.6$ \\
\hline Stigma-corolla separation & $6.6 \pm 2.5$ & $8.3 \pm 4.0$ & $5.6 \pm 2.0$ & $5.3 \pm 2.7$ \\
\hline Stigma-anther separation & $7.9 \pm 2.5$ & $5.7 \pm 3.7$ & $6.0 \pm 1.9$ & $5.3 \pm 2.4$ \\
\hline Stamen height & $27.9 \pm 1.6$ & $35.31 \pm 4.0$ & $25.8 \pm 2.4$ & $31.9 \pm 2.1$ \\
\hline Style plus stigma height & $38.6 \pm 2.7$ & $26.1 \pm 3.2$ & $31.3 \pm 2.7$ & $25.3 \pm 2.2$ \\
\hline Corolla-anther separation & $1.9 \pm 1.1$ & $4.3 \pm 2.0$ & $1.8 \pm 1.2$ & $2.4 \pm 1.1$ \\
\hline No. of corolla lobules & $13.7 \pm 1.2$ & $14.1 \pm 1.4$ & $6.0 \pm 0.5$ & $6.1 \pm 0.4$ \\
\hline No. of stamens & $13.7 \pm 1.3$ & $13.9 \pm 1.4$ & $6.0 \pm 0.5$ & $6.1 \pm 0.5$ \\
\hline
\end{tabular}

dimorphism. Identification of the floral morphs in each species was done by plotting the subject scores computed on the first two principal components (PC) in two-dimension graphs. Visual exploration was used to identify the different floral morphs present in each species. Scores for the first PC were used in a nested ANOVA with random effects, using the MIXED procedure in SAS (Littell et al., 1996) to test differences between floral morphs and between sites, and to estimate the variance components at the plant and flower (flowers nested within plants) hierarchical levels.

Reciprocal herkogamy was estimated graphically and using three indices: the relative reciprocity index of Richards and Koptur (1993), the reciprocity and precision indices of Eckert and Barrett (1994), and the reciprocity index proposed by Sánchez et al. (2008, 2013). Richards and Koptur (1993) index is useful for determining relative reciprocity between organ levels and is calculated for high organ $\left(R_{\text {High }}\right)$ and low organ $\left(R_{\text {Low }}\right)$ levels, as (anther height - reciprocal stigma height) / (anther height + reciprocal stigma height). Values range from 1 to -1 , with zero indicating perfect reciprocity for both organ levels. Eckert and Barrett (1994) reciprocity index provides a simple estimation of the 'equality' of inter-organ distances based on comparison of distances between same sex organs (i.e. stigmas or anthers) in different morphs. Perfect reciprocity $(R I=1)$ is achieved when anthers of one morph are positioned at the same level as the stigma of the other. This reciprocity can be summarized as (anther height short-styled morph - anther height long-styled morph) / (stigma height long-styled morph - stigma height short-styled morph). This precision index $(P I)$ is complementary to the $R I$ and estimates the degree of variation in the distance between anther height and stigma height at the same level. It is calculated using the average variation coefficients of high organ $\left(\mathrm{CV}_{\mathrm{L}}\right)$ and low organ

Table 2. Sampled sites and reciprocity and precision indices according to (1) Richards and Koptur (1993), (2) Eckert and Barrett (1994), and (3) Sánchez et al. (2008). 1: $R_{\text {High }}=$ intermorph reciprocity for high organs and $R_{\text {Low }}=$ intermorph reciprocity for low organs; $2: R I=$ reciprocity index and $P I=$ precision index; $3: R=$ reciprocity index.

\begin{tabular}{|c|c|c|c|c|c|c|c|c|c|c|}
\hline \multirow[b]{2}{*}{ Species } & \multirow[b]{2}{*}{ Sites } & \multirow[b]{2}{*}{$\begin{array}{l}\text { Longitude } \\
\text { (W) }\end{array}$} & \multirow[b]{2}{*}{$\begin{array}{l}\text { Latitude } \\
(\mathrm{N})\end{array}$} & \multicolumn{2}{|c|}{1} & \multicolumn{2}{|c|}{2} & \multirow{2}{*}{$\frac{3}{R}$} & \multicolumn{2}{|c|}{ Plants sampled } \\
\hline & & & & $R_{\text {High }}$ & $R_{\text {Low }}$ & $R I$ & $P I$ & & $\begin{array}{l}\text { Long- } \\
\text { styled }\end{array}$ & $\begin{array}{l}\text { Short- } \\
\text { styled }\end{array}$ \\
\hline \multirow[t]{3}{*}{ C. dodecandra } & $\mathrm{CICY}$ & $89^{\circ} 38^{\prime} 20^{\prime \prime}$ & $21^{\circ} 01^{\prime} 44^{\prime \prime}$ & 0.060 & -0.020 & 0.500 & 10.070 & 0.016 & 4 & 6 \\
\hline & UADY & $89^{\circ} 37^{\prime} 28^{\prime \prime}$ & $20^{\circ} 51^{\prime} 60^{\prime \prime}$ & 0.020 & -0.040 & 0.690 & 10.600 & 0.015 & 4 & 4 \\
\hline & Pooled & & & 0.045 & -0.033 & 0.589 & 10.524 & 0.017 & & \\
\hline \multirow[t]{4}{*}{ C. sebestena } & Chicxulub & $89^{\circ} 34^{\prime} 44^{\prime \prime}$ & $21^{\circ} 17^{\prime} 47^{\prime \prime}$ & 0.034 & 0.007 & 0.718 & 5.680 & 0.004 & 1 & 3 \\
\hline & Uaymitúm & $89^{\circ} 31^{\prime} 17^{\prime \prime}$ & $21^{\circ} 18^{\prime} 40^{\prime \prime}$ & -0.006 & -0.002 & 1.042 & 7.430 & 0.007 & 7 & 6 \\
\hline & Telchac & $89^{\circ} 17^{\prime} 43^{\prime \prime}$ & $21^{\circ} 20^{\prime} 24^{\prime \prime}$ & 0.005 & -0.100 & 0.470 & 8.840 & 0.012 & 1 & 2 \\
\hline & Pooled & & & 0.001 & -0.009 & 0.913 & 7.652 & 0.008 & & \\
\hline
\end{tabular}


$\left(\mathrm{CV}_{\mathrm{S}}\right)$ heights: $\left(\mathrm{CV}_{\mathrm{L}}+\mathrm{CV}_{\mathrm{S}}\right) / 2$. Higher $P I$ values indicate less precision between the organ heights of one morph and another, whereas a zero value represents perfect precision.

The above indices are calculated from a single sex organ height value (e.g., average anther and stigma height for each organ level) and produce two values to estimate organ reciprocity. In contrast, the reciprocity $(R)$ index of Sánchez et al. (2008) results in a single combined reciprocity value for high and low organs, allowing comparison of each organ's height within a population with all possible organ heights. This includes variance in anther-stigma distance within and between populations. Species with perfect reciprocity between short and long organs have zero values, and those exhibiting distyly have values $<0.05$ (Keller et al., 2012). Detailed formulas to compute $R$ can be found in Sánchez et al. (2008).
Complementary data was collected by documenting the morphs present at each site and morph self-incompatibility. Morph ratios were estimated for each species to determine if the floral morph ratio remained equal between sites since this is a characteristic of distylous plants, in sufficiently large populations (Barrett and Shore, 2008; Hodgins and Barrett, 2008). Hand pollination was done using 1,116 flowers in different Cordia dodecandra individuals. Flowering $C$. sebestena individuals were infrequent when the pollination experiment was done, meaning only $C$. dodecandra individuals were used in this experiment. Fully open flowers (bagged from the flower bud stage) of each morph were assigned to one of five treatments: (1) natural conditions, flower left untouched and open to free pollination; (2) spontaneous self-pollination, untouched flower covered with exclusion bag; (3) self-pollination, emasculated flowers received po-
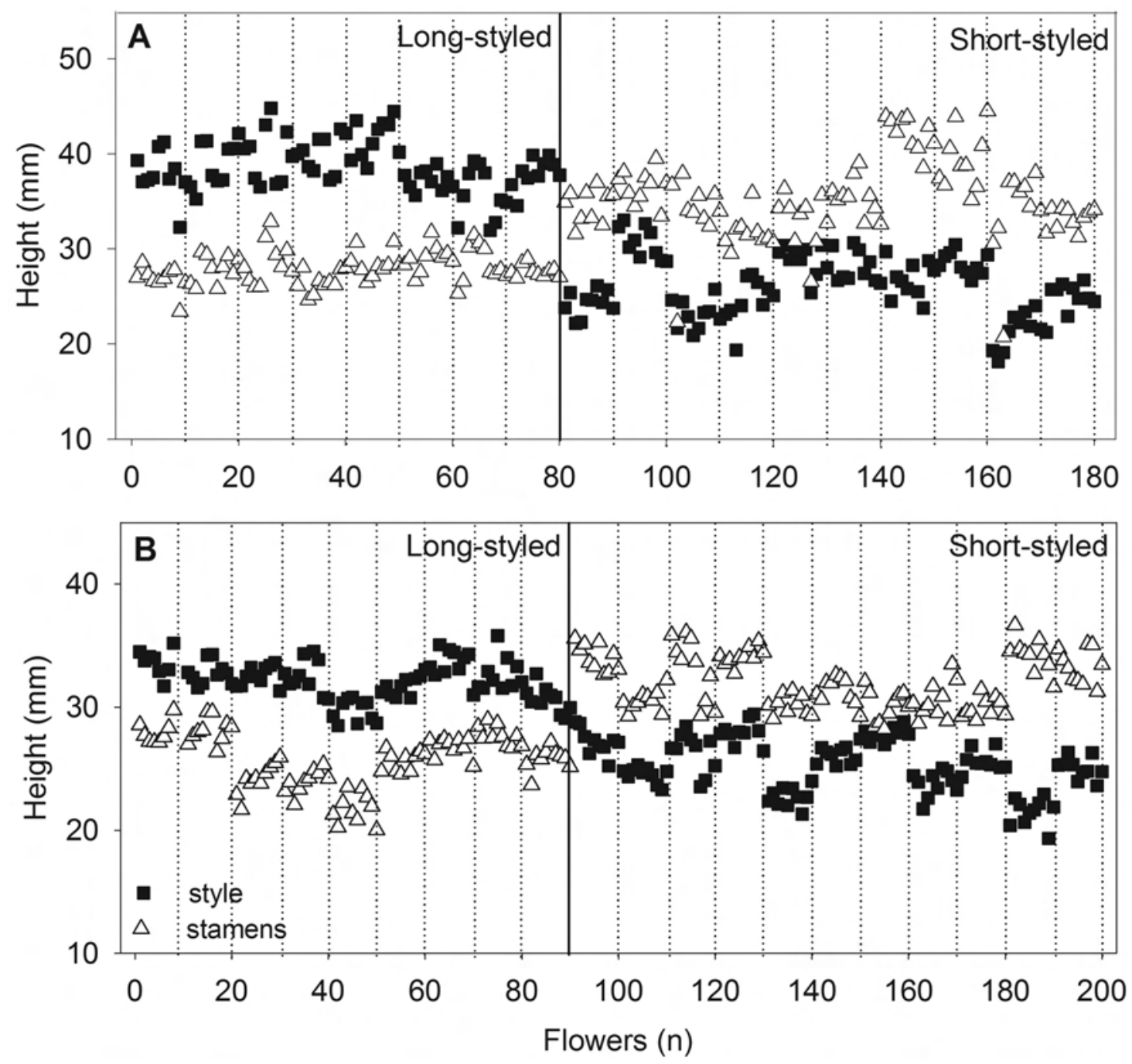

Figure 2. Patterns of variation in style and stamen length in the two Cordia species: (A) C. dodecandra and (B) C. sebestena. For both graphs, styles are solid squares and stamens are represented by open triangles. Flowers of each individual are clustered between dotted lines. The solid line in the middle of each panel separates floral morphs: left side are the long-styled flowers, right side the short-styled ones. 
llen from 1-2 flowers of the same individual; (4) intramorph self-pollination, emasculated flower received pollen from flowers of 1-2 different individuals of the same morph; and (5) intermorph cross-pollination, emasculated flower received pollen from individuals of the opposite morph. Five flowers per inflorescence were assigned to each treatment, labeled after pollination and rebagged until fruit maturity. Fruit production was estimated as the proportion of flowers forming fruit at maturity for each pollination treatment. Differences in fruit production among pollination treatments were tested with the GLIMMIX procedure in SAS using the binomial distribution as the variance function for fruit proportions linked to the generalized linear model with the logit function. Pollination treatment and floral morph were set as fixed factors in the model. Post hoc comparisons were performed using the least square means estimation with the SLICE option to test the effect of pollination treatments for each floral morph when the interaction terms is statistically significant (SAS/STAT, 2006).

\section{Results}

Two floral morphs. The PCA analysis identified two floral morphologies in Cordia dodecandra. The first PC explained $32 \%$ of variation and was determined by stamen height; corolla tube diameter; stigma-anther separation; and corolla diameter (from highest to lowest effect). The second PC (19\%) was determined by stamen number, corolla lobule number, calyx diameter, and corolla tube length. Plotting the PCs identified: one morph having long-styled and short stamens with smaller corollas; the other having short-styled and long stamens with larger corollas. The nested ANOVA showed these morphs to be different $\left(\mathrm{F}_{1,144}=22.18, P<\right.$ 0.0001), confirming the existence of two distylous morphs in $C$. dodecandra. No significant difference was detected between sites in the existence of the two morphs $\left(\mathrm{F}_{1,144}=\right.$ $0.75, P=0.3869)$. In addition, no significant interaction was identified between the factors morph and site $\left(\mathrm{F}_{1,144}=3.81\right.$, $P=0.0529)$. Most intermorph variance in floral morphology was due to interplant variance, independent of site, and accounted for $61 \%$ of total variance in morphology $\left(\mathrm{F}_{17,144}\right.$ $=35.64, P<0.0001)$. Differences between flowers within plants accounted for $<1 \%$ of variance in morphology and was not significant $\left(\mathrm{F}_{18,144}=0.50, P=0.9534\right)$.

Two floral types were also evident in Cordia sebestena by the PCA. The first PC explained $36 \%$ of variation in flower morphology and was mainly determined by stamen height, corolla tube length, corolla diameter and corolla tube diameter. The second PC (17\%) was determined by stigma-anther separation, stigma-corolla separation and calyx length. When plotted, the first and second PCs showed the two floral morphologies: long-styled flowers with short stamens and a smaller corolla, and short-styled flowers with long stamens and a bigger corolla. The nested ANOVA confir- med the difference between floral morphs $\left(\mathrm{F}_{1,152}=11.07\right.$, $P<0.0011)$. No differences were identified among sites $\left(\mathrm{F}_{2,152}=1.85, P=0.1605\right)$, or by the interaction between the morph and site factors $\left(\mathrm{F}_{2,152}=0.57, P=0.5667\right)$. Interplant variance accounted for $73 \%$ of variation in floral morphology $\left(\mathrm{F}_{18,152}=60.84, P<0.0001\right)$. Differences among flowers nested in plants accounted only for $<1 \%$ of total variance in floral morphology $\left(\mathrm{F}_{19,152}=0.34, P=0.9961\right)$.

Reciprocal herkogamy. The pattern of variation in style and stamen length in the two species denoting the typical herkogamy separation between short and long organs in flowers is shown in figure 2. Given the absence of intersite difference in floral morphology for both studied Cordia species, all reciprocity indices were calculated by pooling sampling site data for each species. The reciprocity indices calculated according to Richards and Koptur (1993) showed values near zero for both high $\left(R_{H i g h}\right)$ and low organs $\left(R_{\text {Low }}\right)$ in $C$. dodecandra. This indicates reciprocal matching within high and low organs, that is, stigma height of long-styled flowers matched anther height in short-styled flowers. Results for RI (Eckert and Barrett, 1994) indicated that stigma height in one morph is partially reciprocal with anther height in the other morph, and that the degree of variation $(P I)$ in the distance between anther height and stigma height at the same level is relatively high. Reciprocity $(R)$ values based on Sánchez et al. $(2008,2013)$ indicated that the anther and stigma position observed in different morphs is distinctive of distylous species ( $R$ value $<0.05$; Table 2$)$. For $C$. sebestena, the reciprocity indices of Richards and Koptur (1993) identified close organ reciprocity between morphs both for high $\left(R_{H i g h}\right)$ and low organs $\left(R_{\text {Low }}\right)$. The $R I$ value indicated that stigma height in one morph is closely reciprocal to anther height in the other, and organ positioning precision $(P I)$ is highly accurate for both high and low organs. The $R$ index showed that organ positioning between flowers of different morphs is very near perfect reciprocity (Table 2 ).

Morph ratios and self-incompatibility. When pooled by site, floral morph ratio (long-styled:short-styled) in Cordia dodecandra was almost 1:2 (11 long-styled:19 short-styled) while in C. sebestena it approached 1:1 (54 long-styled:47 short-styled). Experimental crosses in $C$. dodecandra provided evidence for self-incompatibility in flowers of the same morph. Fruit proportion differed among pollination treatments $\left(\mathrm{F}_{4,40}=24, P<0.0001\right)$, but not between floral morphs $\left(\mathrm{F}_{4,40}=0, P=0.99\right)$. Interaction between factors was significant $\left(\mathrm{F}_{4,40}=3.64, P=0.0128\right)$, meaning that the effect of pollination type on fruit production depended on floral morph type. In other words, in both morphs fruit proportion was highest when flowers were pollinated with pollen from the opposite morph (Table 3); however, short-styled morph produced more fruits than long-styled one in the intermorph crosses $(\mathrm{t}=5.62, P<0.0001)$. Pollination under natural con- 
ditions resulted in the second highest fruit production, with long-styled flowers being the most productive $(\mathrm{t}=2.79, P=$ 0.0080 ). No or negligible fruit production was observed in the intramorph self-pollination and spontaneous self-pollination treatments (Table 3).

\section{Discussion}

Both Cordia dodecandra and C. sebestena exhibit distinctive attributes of distyly: (1) two floral morphology types among individuals in each population, long-styled and short-styled flowers; (2) high degree of reciprocal positioning between floral morphs in long and short sexual organs; (3) a floral morph-associated incompatibility system in $C$. dodecandra. Reproductive incompatibility can only be suggested in $C$. sebestena based on population morph ratios.

The variation pattern in distylous traits observed in Cordia dodecandra and $C$. sebestena agrees with that reported in other Cordia species native to the Americas: C. collococca, C. curassavica, C. dentata, C. panamensis and $C$. pringlei (Ganders, 1979). In this pattern, stamen height and stigma-anther separation are the main morphological traits segregating individuals into two floral morphs. However, flower size was also important in identifying each morph in the two studied species (Miller, 1985; Muñoz-Mendoza, 2007). On average, short-styled individuals in both species had flowers with larger corolla size, longer floral tubes and larger calyxes. Increased floral size, derived mainly from long corolla tubes, has been associated with the short-styled morph in other distylous species including several Amsinckia species, genus Glandora, and Lithospermum densiflorum (Boraginaceae; Ganders, 1979; Li and Johnston, 2001; Ferrero et al., 2011); Plumbago auriculata (Plumbaginaceae; Ferrero et al., 2009); Primula vulgaris and P. veris (Primulaceae; Kálmán et al., 2007); Gaertnera vaginata, Guettarda scabra, Palicourea demissa, P. padifolia, Psychotria carthagenensis, and P. nuda (Rubiaceae; Richards and Koptur, 1993; Pailler and Thompson, 1997; Hernández and Ornelas, 2003; Cardoso de Castro and Cardoso-Arau-

Table 3. Average proportion $( \pm \mathrm{SD}$ ) of mature fruit produced under different pollination treatments in Cordia dodecandra. The number of flowers used in each treatment is indicated in parenthesis. Different letters in the same column indicate differences between treatments (Least square means estimation, $P<0.05$ ).

\begin{tabular}{|c|c|c|}
\hline \multirow[b]{2}{*}{ Pollination treatment } & \multicolumn{2}{|c|}{ Floral morphs } \\
\hline & Long-styled & Short-styled \\
\hline Natural conditions & $0.2 \pm 0.1(116)^{\mathrm{a}}$ & $0.1 \pm 0.03(235)^{a}$ \\
\hline Spontaneous selfing & $0.01 \pm 0.01(116)^{b}$ & $0(136)^{b}$ \\
\hline Self-pollination & $0(74)^{b}$ & $0(98)^{b}$ \\
\hline Intramorph crosses & $0(74)^{b}$ & $0(123)^{b}$ \\
\hline Intermorph crosses & $0.5 \pm 0.12(68)^{c}$ & $0.8 \pm 0.1(76)^{\mathrm{c}}$ \\
\hline
\end{tabular}

jo, 2004; Valois-Cuesta et al., 2011; Rodrigues-Faria et al., 2012). In short-styled flowers, corolla tube length probably plays a more important role in positioning sex organs at an appropriate distance, and thus increasing intermorph pollen transfer accuracy, than in long-styled flowers (Pailler and Thompson, 1997; Faivre and McDade, 2001; Kálmán et al., 2007). In C. dodecandra and $C$. sebestena, the stamens are epipetalous and adnated to the corolla in their lower portion. This implies that stamen length increases as the corolla tube elongates, as occurs in $P$. vulgaris and $P$. veris (Kálmán et al., 2007), producing a positive correlation between stamen length, stigma-anther separation and corolla tube length in short-styled morph.

All the indices used here were congruent with reciprocal herkogamy in the two studied species, although this condition was far more marked in Cordia sebestena than in C. dodecan$d r a$. The latter species exhibited less reciprocity between sexual organs in the two morphs and wider variation in organ positioning precision. This lower reciprocity and precision in $C$. dodecandra may diminish pollen transfer accuracy among individuals (Eckert and Barrett, 1995) with far-reaching consequences in pollination success and fruit production. In contrast to previous studies, the $C$. sebestena sampled for the present study exhibited almost perfect reciprocity between floral morphs. Cordia sebestena in Florida have been reported as heterostylous (Tomlinson, 1974), while in southeast Jamaica no clear separation between pistil and stamens was found, although floral dimorphism was observed in corolla tube length (Percival, 1974; Opler et al., 1975). These inconsistencies between studies suggest that herkogamy in flowers may vary considerably at a wider geographic scale. Indeed, shifts in edaphic-climatic conditions and/or pollinator relationships could have triggered the observed variation from distyly to potential homostyly in C. sebestena (Muñoz-Mendoza, 2007). Distylous conditions are usually accompanied by self-incompatibility, genetically preventing intramorph reproduction. This, in turn, promotes symmetrical intermorph mating, resulting in equal morph ratios within populations (Charlesworth and Charlesworth, 1979; Hodgins and Barrett, 2008). In the present study, intramorph incompatibility was confirmed for C. dodecandra at the fruit level. Under natural conditions, higher fruit production was observed in long-styled flowers indicating that pollinators exert an effect on the success of intermorph cross-pollination as it was observed in C. globosa and C. leucocephala from Brazil (Machado et al., 2010). Hummingbirds are the principal pollinators in both the studied Cordia species, suggesting that the probability of the stigma touching the pollen-impregnated head of a hummingbird is greater in long-styled than in short-styled flowers.

Although for intramorph incompatibility was not estimated for Cordia sebestena, the observed floral morph ratio coincides with the morph ratio of a distylous, a self-incompatible system. On the contrary, morph ratio in C. dodecan- 
dra is not consistent with the expected 1:1 distylous ratio. One feasible explanation for the differences in morph ratios between the studied species is that population processes such as seed dispersion and seedling establishment have been disrupted in $C$. dodecandra stands, but have remained viable in $C$. sebestena. This second species still grows in natural stands, whereas $C$. dodecandra now grows largely in former home gardens and are actually remnant trees of original stands. Additionally, an idea still unexplored is that the low reciprocity in sexual organs could increase variance in the reproductive success between morphs, thus biasing the proportion of morphs from the 1:1 expected in distylous populations, as is the case in $C$. dodecandra. On the contrary, high organ reciprocity could promote a more precise pollen deposition between morphs, thus maintaining equal morph proportions within populations, the case in C. sebestena. The quantitative data reported here confirm distyly in C. dodecandra and C. sebestena, highlighting the need for implementing management and conservation practices for both species, but particularly for the drastically declining wild populations of $C$. dodecandra.

\section{Acknowledgements}

The research reported here was financed in part by the CONACYT (Project No. CB 80031), the CICY (Project No. FR0029), and a CICY-CADE 2008 undergraduate scholarship. The authors thank Rodrigo Duno for assistance with floral morphology measurements, Alfredo Dorantes for assistance with field work, Carlos M. Herrera for support with statistical analyses, Sergio Guillén for access to the gardens and laboratories at the Marine Biology Campus of the CCBA-UADY, Rosalina Rodríguez and anonymous reviewers for helpful comments on the manuscript.

\section{Literature cited}

Arroyo J. and Barrett S.C.H. 2000. Discovery of distyly in Narcissus (Amaryllidaceae). American Journal of Botany 87:748751.

Barrett S.C.H. and Shore J.S. 2008. New insights on heterostyly: comparative biology, ecology and genetics. In: Franklin-Tong, V.E. Ed. Self-Incompatibility in Flowering Plants: Evolution, Diversity and Mechanisms, pp. 3-32, Springer-Verlag, Berlin.

Benjamin T.J., Montañez P.I., Jiménez J.J.M. and Gillespie A.R. 2001. Carbon, water and nutrient flux in Maya homegardens in the Yucatán peninsula of México. Agroforestry Systems 53:103111.

Canché-Collí C.H. 2010. Biología reproductiva de Cordia dodecandra D.C. (Boraginaceae): variación de características florales y sistema reproductivo. Thesis, Instituto Tecnológico de Conkal. Conkal, 76 pp.

Cardoso de Castro C. and Cardoso-Araujo A. 2004. Distyly and sequential pollinators of Psychotria nuda (Rubiaceae) in the Atlantic rain forest, Brazil. Plant Systematics and Evolution 244:131-139.
Chan-Vermont C., Rico-Gray V. and Flores J.S. 2002. Guía Ilustrada de la Flora Costera Representativa de la Península de Yucatán. Programa Etnoflora Yucatanense. Fascículo No. 19. Universidad Autónoma de Yucatán, Mérida.

Charlesworth D. and Charlesworth B. 1979. A model for the evolution of distyly. The American Naturalist 114:467-498.

Cohen J.I., Litt A. and Davis J.I. 2012. Comparative floral development in Lithospermum (Boraginaceae) and implications for the evolution and development of heterostyly. American Journal of Botany 99:797-805.

Dulberger R. 1992. Floral polymorphisms and their functional significance in the heterostylous syndrome. In: Barrett S.C.H. Ed. Evolution and Function of Heterostyly, pp. 41-84. SpringerVerlag, New York.

Durán-García R. and Trejo-Torres J.C. 2010. Plantas prioritarias para la conservación. In: Durán-García, R. and Méndez-González, M.E. Eds. Biodiversidad y Desarrollo Humano en Yucatán, pp. 194-196, Centro de Investigación Científica de Yucatán, Programa de Pequeñas Donaciones del Fondo para el Medio Ambiente Mundial, Comisión Nacional para el Conocimiento y Uso de la Biodiversidad, Secretaría de Desarrollo Urbano y Medio Ambiente, Mérida.

Eckert C.G. and Barrett S.C.H. 1994. Tristyly, self-compatibility and floral variation in Decodon verticillatus (Lythraceae). Biological Journal of the Linnean Society 53:1-30.

Eckert C.G. and Barrett S.C.H. 1995. Style morph ratios in tristylous Decodon verticillatus (Lythraceae): selection vs. historical contingency. Ecology 76:1051-1066.

Faivre A.E. and McDade L.A. 2001. Population-level variation in the expression of heterostyly in three species of Rubiaceae: does reciprocal placement of anthers and stigmas characterize heterostyly? American Journal Botany 88:841-853.

Ferrero V., Chapela I., Arroyo J. and Navarro L. 2011. Reciprocal style polymorphisms are not easily categorized: the case of heterostyly in Lithodora and Glandora (Boraginaceae). Plant Biology 13:7-18.

Ferrero V., de Vega C., Stafford G.I., Van Staden J. and Johnson S.D. 2009. Heterostyly and pollinators in Plumbago auriculata (Plumbaginaceae). South African Journal of Botany 75:778-784.

Ganders F.R. 1979. The biology of heterostyly. New Zealand Journal of Botany 17:607-635.

Gottschling M., Miller J.S., Weigend M. and Hilger H.H. 2005. Congruence of a phylogeny of Cordiaceae (Boraginales) inferred from ITS1 sequence data with morphology, ecology, and biogeography. Annals of the Missouri Botanical Garden 92:425-437.

Hernández A. and Ornelas J.F. 2003. Correlación morfo-específica en flores de Palicourea padifolia (Rubiaceae). Boletín de la Sociedad Botánica de México 73:35-41.

Hodgins K.A. and Barrett S.C.H. 2008. Geographic variation in floral morphology and style-morph ratios in a sexually polymorphic daffodil. American Journal of Botany 95:185-95.

Kálmán K., Medvegy A., Pénzes Z. and Mihalik E. 2007. Morphspecific variation of floral traits associated with reciprocal herkogamy in natural populations of Primula vulgaris and Primula veris. Plant Systematics and Evolution 268:15-27.

Keller B., de Vos J.M. and Conti E. 2012. Decrease of sexual organ reciprocity between heterostylous primrose species, with possible functional and evolutionary implications. Annals of Botany 110:1233-1244. 
Li P. and Johnston M.O. 2001. Comparative floral morphometrics of distyly and homostyly in three evolutionary lineages of Amsinckia (Boraginaceae). Canadian Journal of Botany 79:1332-1348.

Littell R.C., Milliken G.A., Stroup W.W. and Wolfinger R.D. 1996. SAS System for Mixed. SAS Institute Inc, Cary.

Machado I.C., Lopes A.V. and Sazima M. 2010. Contrasting bee pollination in two co-occurring distylic species of Cordia (Cordiaceae, Boraginales) in the Brazilian semi-arid Caatinga: generalist in C. globosa vs. specialist in C. leucocephala. Anais da Academia Brasileira de Ciências 82:881-891.

MacKinnon H.B. 2005. Birds and Reserves of the Yucatan Peninsula. Amigos de Sian Ka'an, A.C. Cancún.

McCubbin A. 2008. Heteromorphic self-incompatibility in Primula: Twenty-firstcentury tools promise to unravel a classic Nineteenth century model system. In: Franklin-Tong V.E. Ed. Self-incompatibility in Flowering Plants: Evolution, Diversity, and Mechanisms, pp.289-308, Springer-Verlag, Berlin.

Méndez-González M.E., Durán-García R., Campos-Bobadilla S.M. and Dorantes-Euán A. 2010. Flora medicinal, In: Durán-García, R. and Méndez-González, M.E. Eds. Biodiversidad y Desarrollo Humano en Yucatán, pp. 349-352, Centro de Investigación Científica de Yucatán, Programa de Pequeñas Donaciones del Fondo para el Medio Ambiente Mundial, Comisión Nacional para el Conocimiento y Uso de la Biodiversidad, Secretaría de Desarrollo Urbano y Medio Ambiente, Mérida.

Miller J.S. 1985. Systematics of the genus Cordia (Boraginaceae) in Mexico and Central America. Ph.D. Thesis. Saint Louis University. Misouri. 686 pp.

Miller J.S. and Nowicke J.W. 1989. Sectional placement of some problematic Cordia species (Boraginaceae). Systematic Botany 14:271-280.

Muñoz-Mendoza M.E. 2007. Evolution of dioecy from distyly in the genus Cordia (Boraginaceae): inferences from floral morphometrics, self-incompatibility and sex expression. Ph.D. Thesis. University of Massachusetts Boston. Boston. 174 pp.

Opler P.A., Baker H.G. and Frankie G.W. 1975. Reproductive biology of some Costa Rican Cordia species (Boraginaceae). Biotropica 7:234-247.

Received: May 7th, 2013

Accepted: August 5th, 2013
Pailler T. and Thompson J.D. 1997. Distyly and variation in heteromorphic incompatibility in Gaertnera vaginata (Rubiaceae) endemic to La Reunion Island. American Journal of Botany 84:315-327.

Percival M. 1974. Floral ecology of coastal scrub in southeast Jamaica. Biotropica 6:104-129.

Richards A.J. 1997. Plant Breeding Systems. $2^{\text {nd }}$ ed. Chapman and Hall, London.

Richards J.H. and Koptur S. 1993. Floral variation and distyly in Guettarda scabra (Rubiaceae). American Journal of Botany 80:31-40.

Rico-Gray V., Chemás A. and Mandujano S. 1991. Uses of tropical deciduous forest species by the Yucatecan Maya. Agroforestry Systems 14:149-161.

Rodrigues-Faria, R., Ferrero V., Navarro L. and Cardoso-Araujo A. 2012. Flexible mating system in distylous populations of Psychotria carthagenensis Jacq. (Rubiaceae) in Brazilian Cerrado. Plant Systematics and Evolution 298:619-627.

Sánchez J.M., Ferrero V. and Navarro L. 2008. A new approach to the quantification of degree of reciprocity in distylous (sensu lato) plant populations. Annals of Botany 102:463-472.

Sánchez J.M., Ferrero V. and Navarro L. 2013. Quantifying reciprocity in distylous and tristylous plant populations. Plant Biology 15:616-620.

SAS/STAT. 2006. User's Guide. SAS Institute Inc. Cary <http:// support.sas.com/rnd/app/da/stat/procedures/glimmix.html> (consultado 8 de julio 2013).

Tomlinson P.B. 1974. Breeding mechanisms in trees native to tropical Florida. A morphological assessment. Journal of the Arnold Arboretum 55:269-290.

Valois-Cuesta H., Soriano P.J. and Ornelas J.F. 2011. Dimorphisms and self-incompatibility in the distylous species Palicourea demisa (Rubiaceae): possible implications for its reproductive output. Journal of Plant Research 124:137-146.

Webb C.J. and Lloyd D.G. 1986. The avoidance of interference between the presentation of pollen and stigmas in Angiosperms II. Herkogamy. New Zealand Journal of Botany 24:163-178. 